\title{
WINTER PRICES FOR SUMMER PRODUCTS ON THE EXAMPLE OF APPLES IN SPAIN, POLAND AND LATVIA
}

\author{
Joanna Hernik ${ }^{1}$, Gunta Grinberga-Zalite ${ }^{2}$ \\ ${ }^{1}$ West Pomeranian University of Technology, Poland \\ ${ }^{2}$ Latvia University of Agriculture \\ joanna.hernik@zut.edu.pl; gunta.grinberga@llu.lv
}

\begin{abstract}
Apple trees are the most common fruit tree type in the EU covering 450000 ha. At the global scale, the largest apple exporters are EU-27, China, Chile and the USA, but the largest importers - the EU-27 and Russia. In the EU and Russia, large volumes of apples are imported during the cold time of the year. The market for fresh fruit has traditionally been driven by price, but today's market has become even more dynamic and consumers - more fastidious. The aim of the article is to identify the main determinants influencing prices of fresh fruits and indicate a range of differences between winter and summer prices of fruits based on the example of apples. The current research should be regarded as a 'work in progress', as it will be a part of more extensive research conducted in several EU countries and different times of the year. In the present research, the authors have used comparative analysis, which was based on theoretical literature studies, publications and statistical data available in EUROSTAT databases as well as statistical data aggregated by Spanish, Polish and Latvian market research institutions.
\end{abstract}

Key words: price, fruit, apples, Poland, Spain, Latvia.

\section{Introduction}

Fresh fruits play an important role in our daily diet, because they provide the body with the necessary biologically active substances - vitamins, minerals, organic acids and fibres. Recently, consumption of fresh fruits significantly increases (JuhnevicaRadenkova, 2015). One of the most popular fruit is apple. Apples, and their healing properties, were already known approx. 6500 years BC in the region located between the Black Sea and the Caspian Sea, where they come from. These fruits, rich in many vitamins, were a delicacy of the ancient Romans and Greeks (Vieira, 1999). Scientists believe that apples, which is the most common fruit type in European latitudes, is the fruit that is both rich in antioxidants and full of a fibre called pectin, as a medium-sized apple contains about 4 grams of fibre. Pectin is classed as a soluble, fermentable and viscous fibre, a combination that gives it a huge list of health benefits. The proverb 'An apple a day keeps the doctor away', addressing the health effects of the fruit, dates from 19th century Wales, according to Caroline Taggart, author of 'An Apple a Day: Old-Fashioned Proverbs and Why They Still Work' (Pollan, 2001).

During warm period of the year, a lot of fresh fruits and berries are available in the markets of the EU countries, whereas during wintertime their supply dramatically decreases, especially in colder climate countries, such as Poland and Latvia.

There are many studies supporting a relation between income level and fruit intake, concluding that low-income groups tend to consume lower amounts of fruit and vegetables than higher income groups (Pearson et al., 2009). Moreover, high costs may negatively impact on fruit and vegetable intake levels, too (World Health Organization, 2005). And finally, even people with higher incomes can perceive price as a barrier to consumption of these foods (Kamphuis et al., 2007). The current research is a part of several related research projects that will be devoted to analysis of fruit prices in various EU Member States during different times of the year. The aim of the article is to develop a list of main determinants influencing prices of fresh fruits and indicate a range of differences between winter and summer prices of fruits based on the example of apples. This fruit was selected because nowadays apple trees are the most common fruit tree type in the EU, covering 450000 ha.

The specific research tasks were: 1) to study theoretical aspects of price as an economic category; 2) to characterize Spain, Poland and Latvia as apple producers; 3) to conduct a comparative analysis of apple prices in winter in Spain, Poland and Latvia. In scope of the research, the authors have employed the following methods: theoretical literature studies, analysis and synthesis, comparative analysis method. A graphical method was used for statistical display of research data.

\section{Price as an economic category}

Price, as the value of a product, is debatable. In Roman times (VI-I c. BC) judges, in case of a dispute about the value of goods, were supposed to determine the value regardless of the market price. The judge put himself on one side and on the other side, and then suggested amicable price. This way the concept of just price arose, so the price fair to both parties involved in the transaction. At the time of Diocletian (III-IV c.) fixed prices on all products were introduced and also the death penalty for asserting a higher price. It was thought that in the best interest of the country is to reduce prices in order to provide better living 
conditions for citizens deprived of work and a steady income. Whereas at the period of Thomas Aquinas (XIII c.), fair price included a cost of used materials and a cost of manufacturer's work. Unjustified rising of the price was treated as an unholy fraud. At the end of the Middle Ages, the market became a place for exchange goods but not for getting rich; therefore, prices were set by guilds in an agreement with authorities of cities (Holowka, 2002).

The approach to price has been changed thanks to works of Adam Smith, who introduced the concept of exchange value of goods, which is defined as the quantity of another good, we can get in the process of exchange. If this 'another good' will be a specific sum of money, then we are talking about the price. So, the price is the value of a product expressed in money (Adam Smith Theory of Value, s.a.).

Keynes, in turn, stressed that prices depend on supply and demand. It turns out, however, to be incomplete true, because prices also depend on quantity of money in the market, the willingness of people to save, inflation and deflation, as well as the cost of production, and perhaps even other factors (Keynes, 1946). Nevertheless, certainly supply, demand and price are dynamic elements of the market, and, therefore, are subject to constant change. It should be noted, however, that they do not change spontaneously, but under the influence of market operators activities.

We can agree that the price usually is understood as the value expressed in monetary units, which a buyer is obliged to pay to an entrepreneur for goods or services. It includes the value-added tax and excise tax, if such goods are subjects to such a tax. Price also is defined, as mentioned already, as value of a good, but can also be understood as exchange value, or as a cost that a buyer has to pay, if he/she wants to possess the product (Hernik, 2011). From market point of view, price can encourage or discourage a customer to a purchase. Despite the fact that customers are often not able to determine the value of products, especially in case of a new product without a substitute on the market, the price is a major factor shaping customers' behavior. M. van der Pol, M. Ryan proved that this is true also in case of fruits and vegetables (1996). Table 1 gives evidence to this assumption.

\section{Main factors influencing consumption of vegetables and fruits}

\begin{tabular}{|l|c|}
\hline \multicolumn{1}{|c|}{ Factors } & Total responders (in \%) \\
\hline Price & 42 \\
\hline Taste and family preference & 39 \\
\hline Freshness & 32 \\
\hline
\end{tabular}

\begin{tabular}{|l|l|}
\hline Quality & 27 \\
\hline Availability & 17 \\
\hline Season & 14 \\
\hline
\end{tabular}

Source: M. van der Pol, Ryan, 1996.

In practice of companies` activity, the most often used pricing strategies are the price based on costs, the price set at a level that is acceptable to a customer, and the market price based on decisions of competition.

It is worth noting that the method of pricing also significantly depends on the type and length of distribution channel, so - that is logical - on the product's country (place) of origin.

\section{Spain, Poland and Latvia as apples producers}

The EU fruit sector offers a large number of different products (Eurostat, 2016). The most important fruits in terms of the volume of harvested products are apples (12.7 million tons), oranges (6 million tons) and peaches (2.5 million tons).

Today apple trees are the most common fruit tree type in the EU covering 450000 ha. Poland is the biggest apple growing country with nearly one third of the EU total apple tree area. Italy and Romania follow with each a share of over $11 \%$. France $(8 \%)$, Germany (7\%), Spain (6\%) and Hungary (nearly $6 \%$ ) are also major apple producing countries. Together these seven EU Member States cover more than $80 \%$ of the total EU area under apple trees (Eurostat, 2016).

Spain, Italy, Greece and Portugal are the EU's largest citrus fruit (oranges, small citrus fruits and lemons) producing countries. After apple and citrus fruit trees, peaches (including nectarines) is the most important fruit tree species in the EU with 200000 ha. Spain has the largest producing area for peaches followed by Italy and Greece.

Three European countries: Poland, France and Italy, provide $60 \%$ of the apples' production. Against this background, Latvia is an insignificant manufacturer, because its production covers only $0.1 \%$ of the European market of apples, with production volume of 7800 tons (Table 2, Figure 1).

As it is revealed in Figure 1, Poland occupies the largest market share and the fourth part of the total production is grown exactly in Poland. Remarkable market share leaders are also Italy and France with the market share of $16 \%$ and $19 \%$ accordingly.

The apple orchard farmers admit that apple producing is not a fast and easy business, besides consumers are very sensitive to price increases (Lauku bizness, 2014). In Latvia, the proportion of imported apples constitutes $30-65 \%$ depending on the yield in the current year. Harvested production and average yields of apples during 2010-2014 have been very instable: from 7501 tonnes in 2011 to 14751 tonnes in 2013 (Statistical Yearbook of Latvia, 2015). While 
Production of apples in chosen EU Member States* (in 2015)

\begin{tabular}{|l|c|c|}
\hline \multicolumn{1}{|c|}{ Specification } & $\begin{array}{c}\text { Harvested production } \\
\text { (in } 1000 \text { tons) }\end{array}$ & $\begin{array}{c}\text { Share of EU total harvested production } \\
\text { (in \%) }\end{array}$ \\
\hline BU & $\mathbf{1 2 6 8 5 . 4}$ & $\mathbf{1 0 0 . 0}$ \\
\hline Czelgium & 284.2 & 2.2 \\
\hline Germany & 155.4 & 1.2 \\
\hline Greece & 973.5 & 7.7 \\
\hline Spain & 281.8 & 2.2 \\
\hline France & 593.6 & 4.7 \\
\hline Italy & $\mathbf{1 9 6 7 . 1}$ & $\mathbf{1 5 . 5}$ \\
\hline Hungary & $\mathbf{2 4 4 1 . 6}$ & $\mathbf{1 9 . 2}$ \\
\hline Netherlands & 500.0 & 3.9 \\
\hline Austria & 335.9 & 2.6 \\
\hline Poland & 287.6 & 2.3 \\
\hline Portugal & $\mathbf{3 1 6 8 . 8}$ & $\mathbf{2 5 . 0}$ \\
\hline Romania & 328.2 & 2.6 \\
\hline United Kingdom & 459.6 & 3.6 \\
\hline & 460.0 & 3.6 \\
\hline Latvia & 7.8 & 0.1 \\
\hline
\end{tabular}

* - countries which produce more than 100000 tons.

Source: Production of fruit and vegetables. Eurostat news release, 126, 2016.

in Poland the trend of apple production is growing from 1878000 tonnes in 2010 to 3169000 tonnes in 2015 (Concise Statistical Yearbook of Poland, 2016).

The most popular apple breeds in Latvia are Auksis, Antej, Belorusskoje Malinovoje, Sinap Orlovskij, Lobo. In Poland, most popular breeds are Antonowka, Papierowka, Lobo and Cortland. In Spain: Royal Gala, Granny Smith, Golden Smoothee, Golden Delicious. Generally, in Latvia fruit (including apples) trade balance is distinctively negative, thus the imported products' value is almost three times larger than exported products value (Ministry of Agriculture of the Republic of Latvia, 2016). In Poland, fruit trade balance is almost equable, with slightly bigger import than export. Since Polish fruit producers are struggling with low prices and declining domestic demand, they are looking for new markets outside the EU. In Spain, in 2013, the trade surplus of fruits reached over 5 billion euros. Although Spain produces less than $5 \%$ of apples in EU, this country is the world's third

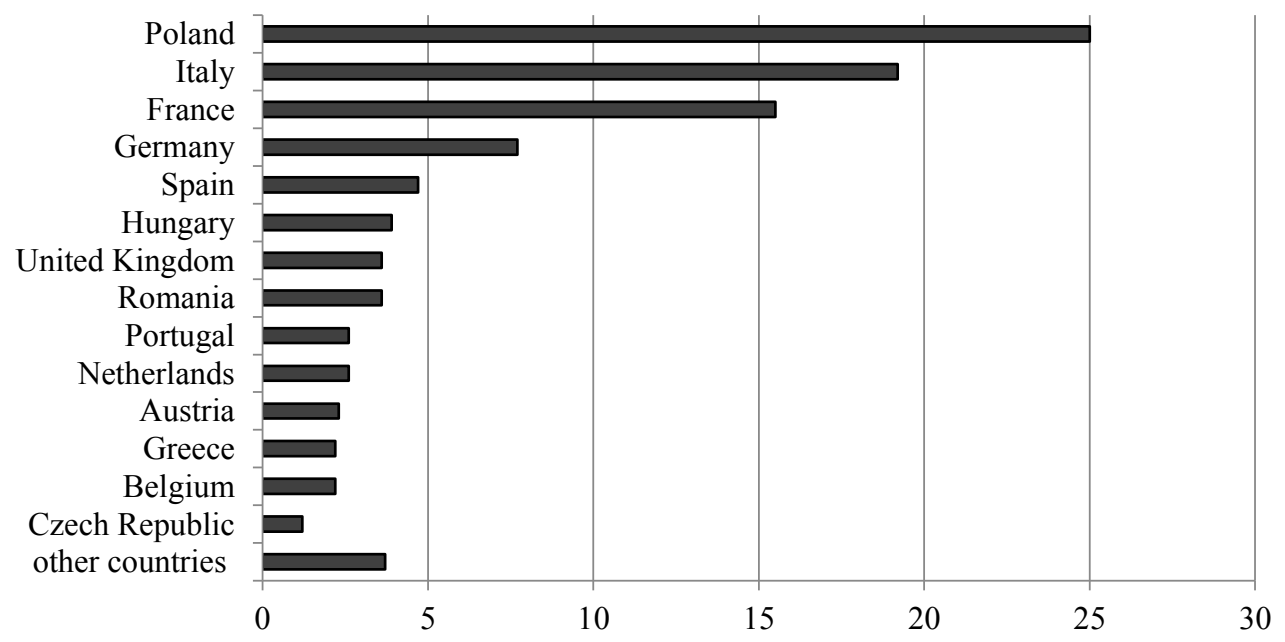

Source: 'Agricultural production - orchards', Eurostat, 2016.

Figure 1. Share of EU total harvested production of apples, $\%$. 
largest exporter of wine, other fruits and vegetables (Spain Exports, s.a.). The European Union accounts for $70 \%$ of Spain's exports.

\section{Apples on the market - comparative analysis}

Apples, of course, can be found in any grocery store in any country (Table 3 ). But, at the same time, consumers can buy a lot of other fruits (Tab. 4). In Spain, there will be: papaya from Brazil; grenade, mango or chirimoya from Spain; kiwi from Chile or bananas from Costa De Marfil (the offer in DIA supermarket in Jaen, Spain, February 2017). In Poland, there can be mango from Brazil, mandarins and oranges from Spain, pineapple from Costa Rica, or pears from Italy (hypermarket Auchan Szczecin, Poland). While in Latvia's largest network of supermarkets RIMI consumers can buy such exotic fruits as pomelo from China, mango from Peru, strawberries from Egypt, or granadilla and pepino from Columbia.

As it is seen in Table 3, the cheaper fruits in February have been in Poland (except oranges and pears), but the most expensive - in Spain (except oranges and pears). The data in Table 3 and 4 show that, in general, prices of fruit in Poland are lower by
$11 \%$ compared to Spain, and by $17.5 \%$ compared to Latvia. In case of apples, prices are also significantly lower in Poland: in Span this fruit costs 259\% more; in Latvia - 207\% more, compared to Poland.

\section{Some conditions of agricultural production: climate} and seasonality

Agriculture uses natural resources; therefore, to a large extent, it dependents on natural environment. The biggest influence on the development of agriculture, among the natural conditions, are climate, water resources, soil, and landform.

Territory of Poland is $312.685 \mathrm{sq} \mathrm{km}$. Of this territory, $48.2 \%$ are used for agriculture and $30.6 \%$ consists of forests. Population of Poland surpasses 38 million, and $15.5 \%$ of economically active population is active in agriculture, although much more (39.5\%) lives in rural areas (FAO, s.a.). The climate is humid continental, with cold, cloudy, moderately severe winters with frequent precipitation, and mild summers with frequent showers. The average summer temperature is between 16.5 and $22{ }^{\circ} \mathrm{C}$; in the winter between -6 and $0{ }^{\circ} \mathrm{C}$. Winter is the longest in the east of the country, where minimum temperatures may

Selling prices of apples in EUR per $100 \mathrm{~kg}$ (in 2015)

Table 3

\begin{tabular}{|l|l|l|c|c|}
\hline \multicolumn{1}{|c|}{ Country } & Price & \multicolumn{1}{c|}{ Country } & Price & Comment \\
\hline Czech Republic & 34.61 & Hungary & 25.80 & \\
\hline Belgium & 39.42 & Spain & & no data \\
\hline Greece & 60.33 & Germany & & no data \\
\hline Austria & 39.04 & France & & no data \\
\hline Netherlands & 48.21 & Italy & 44.58 & \\
\hline Portugal & 59.12 & Poland & $\mathbf{1 8 . 5 9}$ & \\
\hline Romania & 60.06 & Latvia Average & $\mathbf{4 6 . 2 3}$ & \\
\hline United Kingdom & $\mathbf{9 1 . 6 7}$ & & & \\
\hline
\end{tabular}

Source:'Agricultural production - crops', Eurostat, 2016.

Prices of selected fruits and apples (February 2017)

Table 4

\begin{tabular}{|c|c|c|c|c|}
\hline \multirow{2}{*}{} & \multirow{2}{*}{ Name } & Poland & \multicolumn{2}{|c|}{ Spain } \\
\cline { 2 - 5 } & & \multicolumn{3}{|c|}{ Price in euro $\mathrm{kg}^{-1}$} \\
\hline 1 & mandarins & 1.5 & 1.89 & 1.75 \\
\hline 2 & kiwi & 1.6 & 1.99 & 1.79 \\
\hline 3 & bananas & 1.0 & 1.26 & 1.15 \\
\hline 4 & oranges & 0.9 & 0.78 & 0.85 \\
\hline 5 & pears & 1.74 & 0.89 & 1.99 \\
\hline 6 & apples & $\mathbf{0 . 4 6}$ & $\mathbf{1 . 1 9}$ & $\mathbf{0 . 9 5}$ \\
\hline & average & $\mathbf{1 . 2}$ & $\mathbf{1 . 3 3}$ & $\mathbf{1 . 4 1}$ \\
\hline
\end{tabular}

Source: authors' research. 
reach $-20{ }^{\circ} \mathrm{C}$. The average rainfall comes to $600 \mathrm{~mm}$, but a distribution of rainfall during the year is uneven $-2 / 3$ of annual precipitation appears in the summer (mainly July and August), so summers in Poland are rainy. Poland mainly produces potatoes, fruits, and vegetables, when it comes to plant agriculture products. The total area of Spain is $505.370 \mathrm{sq} \mathrm{km}$, with mean elevation of $660 \mathrm{~m}$ (Latvia, for example, has $87 \mathrm{~m}$ of elevation). $54.1 \%$ of the territory is used for agriculture, and $36.8 \%$ as forests. Population of Spain exceeds 48.5 million; $20 \%$ of citizens live in rural areas, but only $4.2 \%$ work in agriculture. Spain produces mainly grain, vegetables, olives, wine grapes, sugar beets, citrus (World Factbook, s.a.). Spanish climate, due to the terrain, varies from cool and rainy in the north-west, after a hot and dry in the plains of Andalusia. Average temperatures are $12{ }^{\circ} \mathrm{C}$ in January and $25^{\circ} \mathrm{C}$ in July, annual rainfall reaches $250 \mathrm{~mm}$. The area of the east and south coast of the country presents characteristics of Mediterranean climate with influence of maritime climate - the more to the south, the hotter is the climate. The average temperatures in July, August and September are 30 ${ }^{\circ} \mathrm{C}$. In Spain, one can enjoy more than 3,000 hours of sunshine per year. In many regions of this country, it snows in winter, especially in the north, despite the fact that an average temperature in January and February is $10-12{ }^{\circ} \mathrm{C}$. The total area of Latvia is $64589 \mathrm{sq}$ $\mathrm{km}$, of which $38 \%$ is considered agricultural land and $44 \%$ forests. Latvia's population is almost 2 million, and $8.8 \%$ works in agriculture. For its latitude, Latvia has a peculiar temperature regime since the maritime temperate climate in the western part is transitional to a more continental one in the eastern part. The climate is characterized by moderately cold winters, while summers are moderately hot. Latvian summers are cool and rainy. The mean July temperature rises to $16-17{ }^{\circ} \mathrm{C}$. Mean annual winter temperatures range from +5 to $-5{ }^{\circ} \mathrm{C}$ in coastal regions; in eastern regions temperatures do not exceed $-15^{\circ} \mathrm{C}$ in winter, and rise to $+30{ }^{\circ} \mathrm{C}$ in summer. Should be noted that over $90 \%$ of the agricultural land in Latvia can only be intensively cultivated if drained. Latvia produces mainly grain, rapeseed, potatoes, and vegetables (Country pasture profiles. FAO, s.a.). When analyzing data on the climate, it can be stated that Poland and Latvia have relatively short and wet summers. In Spain, however, summers are long and warm. This fundamental dissimilarity (Figure 2) forming the seasonality in agriculture makes the production of fruit, including apples, significantly different.

Latvia appears to be in a more difficult situation than Poland, because average temperatures in spring and autumn are lower. Thus, the duration of growing season is similar, but climate for agriculture in Latvia is worse.

Latvian fruit producers face not only the climate among other difficulties in the public survey they have claimed psychological problems of pricing, which still exist in Latvia due to euro adaption in Latvia in 2014. Another threat is cheap and vast supply of Polish apples in Latvia. Finally, the lack of labour force in rural areas, which is very necessary for such industry as apple producing. Moreover, cultivating of apple trees and ensuring their productivity is only one side of this business. The second one, which is even more important, is to find export markets for Latvian apples. Consequently, local market in Latvia is not yet saturated with strong and mature local market players. According to the estimates of the industry specialists, Latvian apples produce constitutes approximately $20 \%$ of all apples supplied to super markets in Latvia. Unlike Poland that has announced an ambitious motivation 'each Pole should eat 15kg of apples per year', Latvia does not specially motivate its population to eat more apples and support local apple producers, which would be nationally important in today's geopolitical circumstances.

\section{Results and Discussion}

Certainly, product quality, price, the reputation or trademark, the freshness and guarantee are some

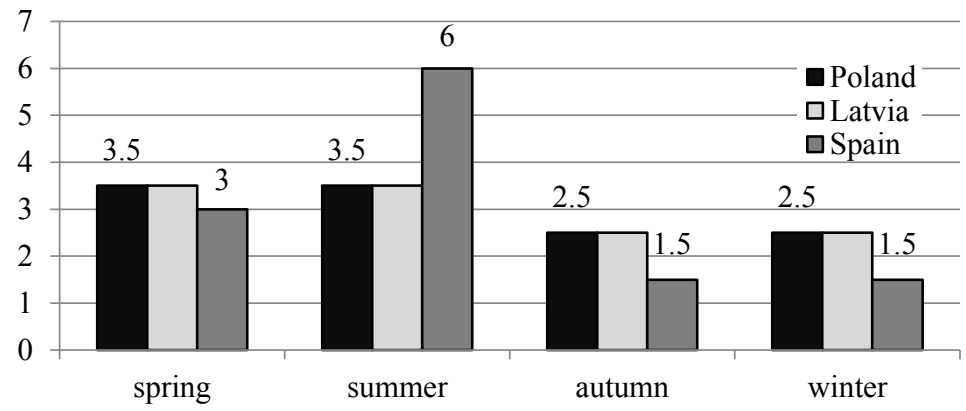

Source: author's design based on internet sources 'Pogoda i klimat w Hiszpanii', 'Pory roku', 'Temperatury i pogoda $w$ Hiszpanii'.

Figure 2. Seasons in Poland, Latvia and Spain (in months). 
of the most important criteria used by European consumers for the general selection of foodstuffs. Of course, consumer penchant for differentiated products is dependent on individual buyer characteristics and of product traits. For example, Rolfe (Rofle et al., 2006) writes that males were more likely to pay higher prices for fruit than females, people who shopped several times a week were more likely to pay higher prices, and people from shared accommodation households and family households were more likely to pay higher prices.

Without doubt, personal characteristics and consumers' style of life play an important role. However, the goal of this article is to agree on a list of main determinants influencing prices of fresh fruits and indicate a range of differences between winter and summer prices, taking price of apples as a starting point. So, in the beginning we can consider (the list definitely is not finished):

1. average salaries;

2. availability of substitute products;

3. climate and geographical location;

4. traditions in consumption.

5. socio-political determinants.

The dynamics of salary changes should be analysed in a close connection with consumption, which provides a more comprehensive overview of the population's welfare. Any household by its consumption expenditure chooses a particular consumption model, which is characterized by particular regularities depending on the household's consumption priorities. One of such regularities was discovered by the German statistician Ernst Engel - the regularity between the household's income and food and non-alcoholic beverages' consumption proportion against the total expenditure. According to modern requirements, the Engel's regularity suggests that alongside with the growth of households' prosperity, their expenditure on food and non-alcoholic beverages increase in absolute numbers and their proportion against the disposable income amount envisaged for consumption decreases (Ciemina, 2009). Average median salary has increased for about $2.39 \%$ in the European Union in 2016, resulting in average EUR 1508 monthly up from EUR 1469 in 2015 (Table 5).

The data aggregated in Table 5 show that the sharpest salary increase in 2016 compared to 2014 has been in Latvia (16.11\%) followed by Romania $(14.03 \%)$ and Bulgaria (12.82\%). However, the standard of living in Latvia, compared to developed European countries is much lower and the average salary comparatively is not competitive. Spain and Poland indicate a moderate increase (accordingly, $7.92 \%$ and $6.22 \%$ ), which is also characteristic to Estonia and Belgium.

The households' consumption structure in the European Union Member States in 2016 suggests that Latvia cannot be brought in line with the welfare standards of highly developed countries, as for e.g. Luxemburg, in which according to the Eurostat data of households' budget survey, the expenditures on food and non-alcoholic beverages of the total consumption expenditure was just $3.3 \%$, while in Latvia they exceed $11 \%$ exceed $15 \%$. Although these indicators are slightly better in Poland and Spain (accordingly, $9.8 \%$ and $8 \%$ ), they significantly lag behind such welfare countries as Luxemburg, Denmark, Germany, the Netherlands and the UK.

\section{Conclusions}

1. The theoretical literature studies give evidence that supply, demand and price are dynamic elements of the market, and, therefore, are subject to constant change. In practice of companies' activity, the most often used pricing strategies are the price based on costs, the price set at a level that

Changes in the average salaries in the European Union between 2014 and 2016

Table 5

\begin{tabular}{|c|l|c|c|c|}
\hline Rank in EU & \multicolumn{1}{|c|}{ Country } & Population & 2014 & 2016 \\
\hline & & Mil & EUR Net & EUR Net \\
\hline 5 & Germany & 80.60 & 2,054 & $\mathbf{2 , 2 2 5}$ \\
\hline 10 & United Kingdom & 64.10 & 2,597 & $\mathbf{2 , 1 1 3}$ \\
\hline 13 & Spain & 46.70 & 1,615 & $\mathbf{1 , 7 5 4}$ \\
\hline 18 & Portugal & 10.40 & 985 & $\mathbf{1 , 0 0 1}$ \\
\hline 20 & Czech Republic & 10.50 & 701 & $\mathbf{7 9 3}$ \\
\hline 22 & Poland & 38.50 & 678 & $\mathbf{7 2 3}$ \\
\hline 24 & Latvia & 2.00 & 557 & $\mathbf{6 6 4}$ \\
\hline 25 & Lithuania & 2.90 & 524 & $\mathbf{5 8 5}$ \\
\hline & & 505.90 & $1,489.43$ & $\mathbf{1 , 5 0 8 . 6 1}$ \\
\hline
\end{tabular}

Source: Average Salary in EU 2016, s.a. 
is acceptable to a customer, and the market price based on decisions of competition. The method of pricing also significantly depends on the type and length of distribution channel, thus it depends on the product's country of origin. Price may also depend on the geographic location. For example, the UK - firstly, it is an island; secondly, there are high salaries in the UK; consequently - these factors lead to limited supply and high wage costs, which causes high prices.

2. Although climate in Spain favors the production of citrus, but not apples, Spain is still the fifth largest producer of apples after Poland (the $1^{\text {st }}$ place in the EU), Italy, France and Germany. Whereas, Latvia is an insignificant manufacturer, because its production covers only $0.1 \%$ of the European market of apples. So, it seems that the volume of domestic production has an impact on a given product price.

3. Price may vary depending on the size and structure of the market; therefore, in Latvia the prices are higher (big market means lowers costs and prices owing to the economy of scale).

4. The cheapest apples are available in Poland, because of a large supply, big market, big individual consumption (patriotic reasons against the embargo of Russia), and vast supply of other fruits. Thus, availability of other fruits from South America, Africa and Asia, can cause low apple prices as well.

\section{References}

1. Adam Smith Theory of Value. Retrieved March 10, 2017, from: http://www.economictheories.org/2008/07/ adam-smith-theory-of-value.html.

2. Eurostat (2017). Agricultural Production - Crops'. Retrieved March 10, 2017, from:http://ec.europa.eu/eurostat/ statistics-explained/index.php/Agricultural_production - crops.

3. Eurostat (2016). Agricultural Production - Orchards. Retrieved March 9, 2017, from: http://ec.europa.eu/ eurostat/statistics-explained/index.php/Agricultural_production_-_orchards.

4. Auglkopibas nozare visa par maz 2014: Lauku bizness (Shortage of Everything in Fruit-growing Industry 2014: Rural Business) (2014). Nr. 157 (4791), p. 12. (in Latvian).

5. Average Salary in EU 2016. Retrieved March 10, 2017, from: https://www.reinisfischer.com/average-salaryeuropean-union-2016.

6. Ciemina, I. (2009). Consumption Expenditure and Trends of Latvian Population in the Past Decade. In Articles of University of Latvia. Economics. Management Science. Volume No. 743. Riga: University of Latvia, pp. $34-42$.

7. Concise Statistical Yearbook of Poland (2016). Warszawa, p. 275.

8. Food and Agriculture Organization of the United Nations (s.a.). Country pasture profiles. Retrieved March 10, 2017, from: http://www.fao.org/ag/agp/agpc/doc/counprof/latvia/Latvia.htm.

9. Eurostat (2016). Agriculture, Forestry and Fishery Statistics. Retrieved March 9, 2017, from: http://ec.europa. eu/eurostat/documents/3217494/7777899/KS-FK-16-001-EN-N.pdf/cae3c56f-53e2-404a-9e9e-fb5f57ab49e3.

10. Hernik, J. (2011). Cena z perspektywy polskich MŚP sfery handlu i usług - metody i strategie, [Price from the perspective of Polish SMEs' sphere of trade and services - methods and strategies] 'Handel Wewnętrzny' 9/10, pp. 307 - 317. (in Polish).

11. Holowka, J. (2002). Etyka w działaniu (Ethics in Action), Proszynksi i S-ka, Warszawa, pp. 271 - 273. (in Polish).

12. Eurostat (2016). Households' Consumption Structure in the European Union Member States in 2016. Eurostat database. Retrieved March 8, 2017, from: http:/ec.europa.eu/eurostat/statistics-explained/index.php/ File:Table_5_COICOP_MSs_GDP.png.

13. Juhnevica-Radenkova, $\bar{K}$. (2015). Impact of Different Storage technologies on Apple Fruit Quality Summary of promotion work for acquiring the Doctor's degree of Engineering Sciences in sector of Food Sciences, Jelgava. $54 \mathrm{p}$.

14. Kamphuis, C.B., van Lenthe, F.J., Giskes, K., Brug, J., \& Mackenbach, J.P. (2007). Perceived Environmental Determinants of Physical Activity and Fruit and Vegetable Consumption among High and Low Socioeconomic Groups in the Netherlands. Health Place 13: 493 - 503.

15. Keynes, J.M. (1946). The General Theory of Employment, Interest and Money, MacMillan, London, p. 265.

16. Ministry of Agriculture of the Republic of Latvia (2016). Informative Material: Monthly Overview of Fruits in 2016.

17. Pearson, N., Biddle, S.J., \& Gorely, T. (2009). Family Correlates of Fruit and Vegetable Consumption in Children and Adolescents: a Systematic Review. Public Health Nutrition 12: 267 - 283.

18. Pogoda i klimat w Hiszpanii (Weather and Climate in Spain). Retrieved March 9, 2017, from: http://www. travelmaniacy.pl/kraj,hiszpania,pogoda-klimat,188.html. (in Polish). 
19. Pol, M. van der, Ryan, M. (1996).'Using Conjoint Analysis to Establish Consumer References for Fruit and Vegetables', British Food Journal, Vol. 98 Iss 8 pp. 5 - 12.

20. Pollan, M. (2001). The Botany of Desire: a Plant's-eye View of the World. Random House. p. 22, cf. p. 9 \& 50.

21. Pory roku (Seasons). Retrieved March 10, 2017, from: http://encyklopedia.interia.pl/geografia/news-poryroku,nId,2064629. (in Polish).

22. Prices of Fruit and Vegetables (2015). Statistical Yearbook of Latvia 2015, p. 259.

23. Production of Fruit and Vegetables. Apples and tomatoes were the top fruit and vegetable produced in the EU in 2015 Spain, Italy and Poland: main producers, Eurostat news release, 126/2016 - 22 June 2016, p. 3. Retrieved March 10, 2017, from: http://ec.europa.eu/eurostat/documents/2995521/7517627/5-22062016-APEN.pdf/8247b23e-f7fd-4094-81ec-df1b87f2f0bb.

24. Rolfe, J., Bretherton, Ph., Hyland, P., \& Soosay, C. (2006). 'Statistical Techniques to Facilitate the Launch Price of Fresh Fruit. Bringing science to the art of pricing', British Food Journal, Vol. 108 Iss 3 pp. $200-212$.

25. Spain Exports. Retrieved March 9, 2017, from: http://www.tradingeconomics.com/spain/exports.

26. Temperatury i pogoda w Hiszpanii (Temperatures and weather in Spain). Retrieved March 11, 2017, from: http://www.travelplanet.pl/przewodnik/hiszpania/temperatury. (in Polish).

27. Vieira, E.R. (1999). Elementary Food Science, Springer Science \& Business Media, New York, p. 105.

28. World Factbook (2017). Country Profiles. Retrieved March 11, 2017, from: https://www.cia.gov/library/ publications/the-world-factbook/geos/lg.html.

29. World Health Organization (2005). Effectiveness of Interventions and Programmes Promoting Fruit and Vegetable Intake. WHO: Geneva, Switzerland. Retrieved March 10, 2017, from: http://www.who.int/ dietphysicalactivity/publications/f\%26v_promotion_effectiveness.pdf. 